\title{
Shade, fertilizers and a natural bioregulator to improve Zantedeschia growth in a Mexican tropical upland area ${ }^{1,2}$
}

\author{
Juan Guillermo Cruz-Castillo ${ }^{3}$, Juvencio Mendoza-Ramírez ${ }^{4}$ \\ and Pablo Alberto Torres-Lima ${ }^{5}$
}

J. Agric. Univ. P.R. 85(3-4):135-142 (2001)

\begin{abstract}
This work reports research on effects of light intensity, fertilizers, and Organozyma ${ }^{6}$ (a natural bioregulator compound) on the growth and floral quality of potted calla lily cv. Green Goddess [Zantedeschia aethiopica (L) $\mathrm{K}$. Spreng] growing in a tropical upland. The highest number of leaves (6.4) was produced under $35 \%$ shade using polypropylene material and soil application of fertilizer N P K Mg 12-11-18-3. The treatment with fewest leaves (2.4) was obtained by applying to the soil N K 14-40 for plants in full sun. The plant length $(50.4 \mathrm{~cm})$, floral peduncle length $(73.1 \mathrm{~cm})$, spathe width $(13.8$ $\mathrm{cm})$ and spadice length $(5.5 \mathrm{~cm})$ were significantly greater $(P \leq 0.05)$ in plants $50 \%$ shaded than in those exposed to full sun. The largest leaf area $\left(508 \mathrm{~cm}^{2}\right)$ was recorded in plants under $50 \%$ shade treated with applications of N P K Mg 12-11-18-3 (soil), and N P K 20-30-10 + Organozyma@ (foliar). The plants producing the most individual shoots per pot $(5.0)$ were also treated with 12-11-18-3 + 20-30-10 + Organozyma@ irrespective of the light treatments. In another experiment, tubers of 'Cameo' $[Z$. albomaculata (Hook) Bail] were dipped in Organozyma ${ }^{8}$. These tubers produced an average 5.6 shoots; the controls, only 4.4 .
\end{abstract}

Key words: Zantedeschia aethiopica, Z. albomaculata, Green Goddess, natural bioregulators, artificial shade, new crops, aroids

\section{RESUMEN}

Se estudió el efecto de la intensidad luminica, fertilizantes y Organozyma $₫$ (compuesto natural de bioreguladores) sobre el crecimiento y cali-

'Manuscript submitted to Editorial Board 13 November 2000.

"The authors thank MSc. E.V. Cruz-San Pedro and Dr. Linda Wessel-Beaver for their comments.

'Researcher, Centro Regional Universitario Oriente, Universidad Autónoma Chapingo, Aptdo. 49, Huatusco, Veracruz. 94100. México. Emaili cruo_uach@iqia.com.mx

'Student, Bachellor in Tropical Agriculture, Universidad Autónoma Chapingo.

"Researcher, Departamento de Producción Agrícola y Animal. Universidad Autónoma Metropolitana-Xochimilco, Calzada del Hueso 1100, Col. Villa Quietud, Coyoacán 04960, México, D.F.

"Trade names in this publication are used only to provide specific information. Mention of a trade name does not constitute a warranty of equipment or materials by the Agricultural Experiment Station of the University of Puerto Rico, nor is this mention a statement of preference over other equipment or material. 
dad floral del lirio cala o alcatraz cv. Green Goddess [Zantedeschia aethiopica (L) K. Spreng] en macetas establecidas en una región tropical de altura. El mayor número de hojas (6.4) se obtuvo al aplicar al suelo el fertilizante N P K Mg 12-11-18-3, con un sombreado con malla de polipropileno al $35 \%$. El menor número de hojas (2.4) se obtuvo con aplicaciones al suelo del fertilizante $N$ K 14-40 en plantas expuestas directamente al sol. El tamaño de la planta $(50.4 \mathrm{~cm})$, la longitud del pedúnculo floral $(73.1 \mathrm{~cm})$, el ancho de la espata $(13.8 \mathrm{~cm})$, y el largo del espádice $(5.5 \mathrm{~cm})$ fueron significativamente mayores $(P \leq 0.05)$ en las plantas sombreadas con malla de material polipropilénico al $50 \%$ que en aquéllas expuestas directamente a la luz solar. La mayor área foliar $\left(508 \mathrm{~cm}^{2}\right)$ fue determinada en plantas sombreadas con malla al $50 \%$ y fertilizadas al suelo y a las hojas con 12-11-18-3, y $20-30-10$ + el promotor natural de crecimiento, Organozyma ${ }^{\circledR}$. Las plantas que produjeron el mayor número de hijuelos/maceta (5.0) fueron también aquéllas tratadas con 12-11-18-3 y 20-30-10 + Organozyma@. En otro experimento, tubérculos del lirio cala 'Cameo' [ $Z$, albomaculata (Hook) Bail.] fueron tratados con Organozyma®. Estos tubérculos tuvieron en promedio 5.6 individuos brotados por tubérculo; en cambio, los tubérculos que no fueron tratados tuvieron solamente 4.4 .

\section{INTRODUCTION}

In Mexico, the cut flower production area is 10,000 ha and most of the production systems are not protected (Pizano, 1997). In the subtropical uplands of the State of Veracruz, above 1,800-m elevation, there are about 50 ha of white calla lily [Zantedeschia aethiopica (L) K. Spreng] produced mostly inside corn or potato crop fields of small farmers. Although callas are described as temperate plants (Funnell, 1993) their production under tropical conditions is found in Puerto Rico (Ruiz-Sifre et al., 1996). Callas are in great demand in Mexican and other overseas markets (Cruz and Cárdenas, 1997), and their flower production may represent additional returns for Mexican peasants living in tropical uplands of the State of Veracruz at an elevation of 1,000 to $2,000 \mathrm{~m}$. Despite this plant's increasing economic importance in Mexican religious ceremonies and crafts, few data currently exist concerning calla production systems in the tropics of Mexico (Cruz-San Pedro et al., 1996; Cruz and Cárdenas, 1997). The 'Green Goddess' calla lily [Zantedeschia aethiopica (L) K. Spreng] is a perennial and has attractive green-white spathes; thus, it is of high value in domestic markets. In preliminary field studies, we saw adequate growth and development of this calla in a coffee bean production area in the State of Veracruz (Cruz and Cárdenas, 1997). However, leaf damage may appear in spring and summer on callas growing in full sun. Plants of Zantedeschia aethiopica 'Childsiana' become chlorotic with high light intensities regardless of temperature (Funnell, 1993). Fertilizers have been applied to improve flower quality in potted callas (Reiser and Langhans, 1993; Ngamau, 2001). However, the effect of different light intensities and their interaction with fertilizer applications on Green Goddess calla growth was 
not found in the literature. Therefore, studies on Green Goddess calla fertilization and light intensity management are required before recommending cultural practices in tropical uplands.

The application of Gibberellic Acid $\left(\mathrm{GA}_{3}\right)$ alone (Corr and Widmer, $1987)$ or mixed with another gibberellin $\left(\mathrm{GA}_{7}\right)$ and the citoquinin bencil adenine purine (BAP) (Funnel et al., 1992) promotes bud sprout of calla tubers. Positive effects of natural bioregulator applications on calla growth may represent an alternative in specific production systems where callas form part of an organic garden. Organozyma ${ }^{\circledR}$ is a natural compound rich in saponins ( $43.5 \%$ ), and it also contains natural gibberellins $(0.39 \%)$, citoquinins $(0.62 \%)$, and humic acids $(8.22 \%)$. The saponins are secondary metabolites of the plant cell mainly found in the membranes. They may promote seed germination or inhibit root growth (Valencia, 1995). Humic acid promotes plant growth by the improvement of soil water-holding capacity, cation exchange capacity, and organic matter in soil applications (Reynolds et al., 1995). Sprayed on apple leaves, humic acids provoked stomata opening (Reyes, 1993). In the present work, we studied the influence of light intensity, fertilizers, and Organozyma $1 B$ on the growth of Green Goddess calla under upland tropical conditions. We also determined tuber growth response to Organozyma® of the calla cv Cameo [Z. albomaculata (Hook) Bail] with peach cream color spathes.

\section{MATERIALS AND METHODS}

\section{Experiment 1.}

The experiment was conducted in the Centro Regional Universitario Oriente of the Universidad Autónoma Chapingo in Huatusco, Veracruz, Mexico $\left(19^{\circ} 08^{\prime} 48^{\prime \prime} \mathrm{N}, 96^{\circ} 57^{\prime} 00^{\prime \prime} \mathrm{W}\right)$, at 1340 -m elevation. The experimental work started in mid January and ended June 1999. During that period the total precipitation was $508 \mathrm{~mm}$ and temperature averaged $17.5^{\circ} \mathrm{C}$.

Individual Green Goddess calla lily plants about $20 \mathrm{~cm}$ high were selected and dipped in a fungicide-bactericide solution of Agrimicu $500 \circledR$ $3.0 \mathrm{~g} / \mathrm{L}$ for $15 \mathrm{~min}$. Each of the 108 callas was planted in rigid black plastic containers $28 \mathrm{~cm}$ in diameter and $25 \mathrm{~cm}$ tall. The bottom half of the containers were filled with sifted clay loam soil with $5.56 \mathrm{pH}, 2.4$ $\mathrm{mg} / \mathrm{kg} \mathrm{P}, 0.376 \mathrm{cmol} / \mathrm{kg} \mathrm{K}$, and $4.7 \%$ organic matter. Compost from wood material was added to fill the containers. In each container $50 \mathrm{ml}$ of the fungicide-nematicide Furadan ${ }^{\circledR} 2.5 \mathrm{ml} / \mathrm{L}$ was applied one week after callas were planted. The plants were exposed to three different irradiance treatments: full sun, and $35 \%$ and $50 \%$ shade from polypropylene 
material. On a cloudy April day of 1999 at 11 a.m., the photosynthetic active radiation (PAR) was measured with the LI-6200(B) portable photosynthesis system. Full sun, 35\% and $50 \%$ shade treatments had 629.73 $\mu \mathrm{mol} / \mathrm{m}^{2} / \mathrm{s}, 477.61 \mu \mathrm{mol} / \mathrm{m}^{2} / \mathrm{s}$, and $149.85 \mu \mathrm{mol} / \mathrm{m}^{2} / \mathrm{s}$ of photon flux, respectively. In addition to the irradiance treatments, five different chemical applications together with untreated plants were evaluated: (1) $\mathrm{N} \mathrm{K}=$ 14-00-40; (2) N P K = 20-30-10; (3) N P K = 15-30-15; (4) N P K Mg = 12-11-18-3; and (5) N P K Mg = 12-11-18-3 + 20-30-10 + Organozyma ${ }^{\circledR}$ (Ultrateck Laboratories). Organozyma $₫$ is a natural compound extracted from Yuca schidiger and Ascophyllum nodosum containing $43.5 \%$ saponins, $0.3 \%$ natural gibberellins, $0.6 \%$ citoquinins, $8.2 \%$ humic acid, $26.7 \%$ organic matter, $0.2 \% \mathrm{~N}, 1.5 \% \mathrm{~K}_{2} \mathrm{O}, 0.08 \% \mathrm{Mg}$, and $5.0 \% \mathrm{Ca}$. All treatments were applied four times every 20 days after planting. Soil fertilizer applications were of $20 \mathrm{~g} / \mathrm{pot}$ for the first four treatments. In the last treatment, $20 \mathrm{~g} /$ pot of $12-11-18-3$, and $4 \mathrm{~g} / \mathrm{L}$ of $20-30-10+15 \mathrm{ml} / \mathrm{L}$ Organozyma ${ }^{\circledR}$ were applied to the foliage. The treatments were arranged in a two-factor, split plot randomized complete block design with six replications represented by six individual small structures where the main plot treatments were the irradiance levels randomly arranged. Different parts of each structure were covered with the proper polypropylene material, and a full sun treatment was also established. The subplots involved the five different fertilizer applications and the untreated plants arranged under each irradiance level. One potted plant was the experimental unit where the following measured variables were determined: number of leaves per plant, plant height $(\mathrm{cm})$ two or three days before the opening of the spathe, floral peduncle length $(\mathrm{cm})$, spathe width $(\mathrm{cm})$, spadice length $(\mathrm{cm})$, leaf area $\left(\mathrm{cm}^{2}\right)$ in three leaves per plant (using the CI-400® computer image analysis system), and number of emerged shoots per pot. These variables were determined in May and June 1999. The data were analyzed by ANOVA using the PROC GLM and LSMEANS of SAS to obtain mean differences (SAS, 1989).

\section{Experiment 2.}

We used three hundred calla tubers of the cv Cameo 2.0 to $2.5 \mathrm{~cm}$ wide and 3.5 to $4.0 \mathrm{~cm}$ long, weighing about $16 \mathrm{~g}$. Half of the tubers were dipped for $5 \mathrm{~min}$ in a solution of $15 \mathrm{ml} / \mathrm{L}$ of Organozyma® and then two tubers per pot were planted in each of 75 containers which were randomized with another 75 pots containing untreated tubers. All the tubers were treated with $1 \mathrm{ml} / \mathrm{L}$ of the iodine compound Ultradine $\circledR$ to prevent disease. Before the Organozyma® treatment, the tubers had been stored 18 weeks in a carton containing sawdust at room temperature averaging about $21^{\circ} \mathrm{C}$. The location of this study, and the size and 
substrate of the containers were as in experiment 1 . A completely randomized design was used to evaluate the treatments. The experimental unit was one pot. The measured variables were fresh tuber weight and number of emerged shoots per tuber. Tubers were planted in February and variables evaluated July 1999. The data were analyzed by the procedure TTEST of SAS for independent samples (SAS, 1989).

\section{RESULTS AND DISCUSSION}

Light intensity, fertilizer, and their interaction significantly affected the number of leaves and leaf area $(\mathrm{P} \leq 0.05)$ in the ANOVA. Calla lily plants under $35 \%$ and $50 \%$ shade produced plants with 4.5 and 4.7 leaves, respectively, significantly different $(P \leq 0.05)$ from full sun plants, which had 3.2 leaves across all fertilizer treatments (data not shown). Plants treated with fertilizer N P K Mg 12-11-18-3 showed the highest number of leaves (5.0) in comparison with those fertilized with N K 14-40 (3.7) and those chemically untreated (3.1), irrespective of the three light intensity treatments (data not shown). Plants treated with 12-11-18-3 growing under 35\% shade achieved the highest value with 6.4 leaves per plant. In contrast, callas with this chemical treatment and grown at full sun and $50 \%$ shade had 4.0 and 4.6 leaves per plant, respectively. The lowest number of leaves (2.4) was observed on full sun plants soil-treated with 14-40 (Table 1). With respect to leaf area, the largest leaves were found in plants shaded $50 \%$ and the smallest in full sun. All the chemical treatments promoted larger leaf area in comparison with that of chemically untreated plants. The largest leaf area $\left(508 \mathrm{~cm}^{2}\right)$ was recorded on plants growing under $50 \%$ shade treated with 12-11-18-3 + 20-30-10 + Organozyma®, but when these plants were shaded $35 \%$ and in full sun they had an average leaf area reduction of $48.9 \%$ (Table 1). The untreated plants in full sun had lower leaf area than those shaded (Table 1). Spathe length was influenced by a significant interaction between light intensities and fertilizers. The callas with the longest spathe length were those with the 15-30-15 fertilizer in $50 \%(22.2 \mathrm{~cm})$ and $35 \%(22.4 \mathrm{~cm})$ shade, but low values were found in full sun plants treated with this fertilizer $(17.1 \mathrm{~cm}$ ) (Table 1). Therefore, the application of these fertilizers on plants at certain levels of light intensity is useful to increase flower quality in plants growing on the substrate used in this work. The spadice length, spathe width, plant height, and peduncle length (Table 2) were significantly larger $(\mathrm{P} \leq 0.05)$ in the shaded treatments (Table 2$)$. Other researchers have shown that Zantedeschia plants adapt well to low photosynthetic photon flux regimes (Funnell, 1993), and reducing light intensities increases vigor and floral quality (Corr and Widmer, 1990; Cruz and 
TABLE 1.-Interaction effects between light intensities and chemical treatments on number of leaves, foliar area, and spathe length of Green Goddess Zantedeschia aethiopica.

\begin{tabular}{|c|c|c|c|c|}
\hline $\begin{array}{l}\text { Irradiance } \\
(\%)\end{array}$ & $\begin{array}{c}\text { Treatments } \\
\text { (N P K, N P K Mg } \pm \text { Organozyma(i)') }\end{array}$ & $\begin{array}{l}\text { No. of } \\
\text { leaves }\end{array}$ & $\begin{array}{l}\text { Foliar } \\
\text { area } \\
\left(\mathrm{cm}^{2}\right)\end{array}$ & $\begin{array}{l}\text { Spathe } \\
\text { length } \\
(\mathrm{cm})\end{array}$ \\
\hline 50 & $14-00-40$ & 4.8 & 463.6 & 22.4 \\
\hline 50 & $20-30-10$ & 4.1 & 461.6 & 15.0 \\
\hline 50 & $15-30-15$ & 5.0 & 473.2 & 22.2 \\
\hline 50 & $12-11-18-3$ & 4.6 & 385.6 & 19.0 \\
\hline 50 & $12-11-18-3+20-30-10+$ Organozyma® & 4.6 & 508.0 & 22.8 \\
\hline 50 & Untreated & 3.8 & 297.3 & 14.9 \\
\hline 35 & $14-00-40$ & 4.0 & 389.6 & 20.9 \\
\hline 35 & $20-30-10$ & 5.6 & 410.3 & 18.7 \\
\hline 35 & $15-30-15$ & 4.0 & 315.6 & 22.4 \\
\hline 35 & $12-11-18-3$ & 6.4 & 372.0 & 16.7 \\
\hline 35 & $12-11-18-3+20-30-10+$ Organozyma & 4.2 & 330.6 & 19.7 \\
\hline 35 & Untreated & 4.0 & 242.3 & 14.5 \\
\hline 100 & $14-00-40$ & 2.4 & 260.6 & 15.7 \\
\hline 100 & $20-30-10$ & 3.2 & 144.0 & 15.2 \\
\hline 100 & $15-30-15$ & 3.1 & 220.6 & 17.1 \\
\hline 100 & $12-11-18-3$ & 4.0 & 215.6 & 16.4 \\
\hline 100 & $12-11-18-3+20-30-10+$ Organozyma(B) & 3.0 & 190.6 & 18.1 \\
\hline \multirow[t]{2}{*}{100} & Untreated & 3.8 & 189.6 & 13.2 \\
\hline & Standard error ${ }^{2}$ & 0.3268 & 13.883 & 0.6405 \\
\hline
\end{tabular}

${ }^{1}$ Natural compound containing saponins $(43.5 \%)$, gibberellins $(0.3 \%)$, citoquinins $(0.6 \%)$, humic acid $(8.2 \%)$, organic matter $(26.7 \%), \mathrm{N}(0.2 \%), \mathrm{K}_{2} \mathrm{O}(1.5 \%), \mathrm{Mg}(0.08 \%)$, and $\mathrm{Ca}(5.0 \%)$.

${ }^{2}$ Standard error of the difference between any two means (irradiance $\times$ treatment combinations).

Cárdenas, 1997). Our results indicated that natural full sun intensity may limit the adequate growth of Green Goddess calla in Huatusco, and shade can improve growth and floral quality. The number of individual shoots per pot was increased significantly by applying 12-11-18$3+20-30-10+$ Organozyma ${ }^{\circledR}$. This treatment produced 5.0 individual shoots per pot whereas control plants had only 2.9 (Table 2). Applications of $\mathrm{GA}_{3}$ alone (Dennis et al., 1994) or mixed with BAP (Funnell et al., 1992) have been effective to increase the number of buds emerging as primary shoots in Zantedeschia hybrids and in Green Goddess Zantedeschia aethiopica (Ngamau, 2001). In the present work, the natural compound Organozyma(B) enhanced the effect of fertilizer on the promotion of the number of shoots per plant (Table 3). The effects of light 
J. Agric. Univ. P.R. VOL. 85, NO. 3-4, JULY-OCTOBER 2001

TABLE 2.-Irradiance level effects in. Green Goddess Zantedeschia calla on plant height (before the opening of the spathe), pedancle length, spathe width, and spadice length.

\begin{tabular}{lcccc}
\hline $\begin{array}{l}\text { Irradiance } \\
(\%)\end{array}$ & $\begin{array}{c}\text { Plant height } \\
(\mathrm{cm})\end{array}$ & $\begin{array}{c}\text { Peduncle length } \\
(\mathrm{cm})\end{array}$ & $\begin{array}{c}\text { Spathe width } \\
(\mathrm{cm})\end{array}$ & $\begin{array}{c}\text { Spadice length } \\
(\mathrm{cm})\end{array}$ \\
\hline 50 & 50.44 & 73.15 & 13.80 & 5.48 \\
35 & 44.72 & 58.85 & 11.48 & 5.01 \\
100 & 36.16 & 39.74 & 9.33 & 4.05 \\
Standard error & 1.635 & 1.928 & 0.290 & 0.183 \\
\hline
\end{tabular}

intensity and its interaction with the fertilizer were not significant for this variable. Thus, specific adequate nutrition is important to increase the number of individual shoots or flowers per plant irrespective of light intensities tested in this work. Organozyma® might be included in a fertilizer program for Green Goddess calla propagation systems.

In the second experiment, the number of individual shoots per tuber of Zantedeschia cv Cameo were significantly increased $(\mathrm{P} \leq 0.05)$ by dipping the tubers in Organozyma® $15 \mathrm{ml} / \mathrm{L}$. Treated tubers achieved on average 5.7 emerged shoots per tuber; untreated tubers, 4.4. No significant effects have been observed with preplant Zantedeschia applications of the cytocinins Thidiazuron ( $N$-phenyl- $N$ 1,2,3,-thiadia-

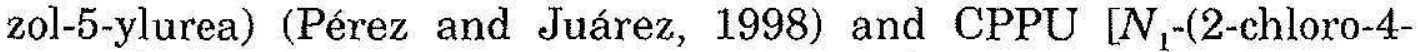
pyridyl)- $N_{3}$ phenylurea] (B. MacKay, 1994, Massey University, New Zealand, personal communication). However, in these field studies, the application of Organozyma ${ }^{\circledR}$ as foliar treatments influenced the promotion of individual shoots per pot (Table 3) and may be an alternative to preplant GA treatments. The Cameo tuber fresh weight was not significantly affected by the application of Organozyma ${ }^{\circledR}$. Calla production

TABLE 3.-Fertilizer effects on number of emerged shoots per pot in Green Goddess Zantedeschia calla.

Treatments

(N P K, N P K Mg \pm Organozyma(B)

Number of emerged shoots

\begin{tabular}{ll}
\hline $14-00-40$ & 4.0 \\
$20-30-10$ & 3.0 \\
$15-30-15$ & 3.8 \\
$12-11-18-3$ & 3.7 \\
$12-11-18-3+20-30-10+$ Organozyma®1 & 5.0 \\
Untreated & 2.9 \\
Standard Error & 0.3073 \\
\hline
\end{tabular}


systems in the tropics are limited because of the bacterial soft rot attack caused by Erwinia carotovora at high temperatures (Wright, 1998). In the present work, the diseases were reduced in the Green Goddess and Cameo plants under shade, and 15\% of Green Goddess full sun plants rotted.

\section{LITERATURE CITED}

Corr, B. E. and R. E. Widmer, 1990. Growth and flowering of Zantedeschia elliottiana and Z. rehmannnii in response to environmental factors. HortScience 25(8):925-927.

Corr, B. E. and R. E. Widmer, 1987. Gibberellic acid increases flower number in Zantedeschia elliotiana and $Z$. rehmannii. HortScience 22(4):605-607.

Cruz, C. J. G. and A. M. Cárdenas, 1997. El alcatraz (Zantedeschia spp): un cultivo nuevo para el trópico de Veracruz, México. Proc. Interam. Soc.Trop. Hort. 41:84-87.

Cruz-San Pedro, E. V., M. T. Colinas-León, H. Sahagún-Castellanos and $\mathrm{H}$. LozoyaSaldaña, 1996. Soluciones preservadoras y perfiles enzimáticos en postcosecha de inflorescencias de alcatraz (Zantedeschia aethiopica L. Spreng). Revista Chapingo. Serie Horlicultura 2(2):161-170.

Dennis, D. J., J. Doreen and T. Ohteki, 1994. Effect of a gibberellic acid 'quick-dip' and storage on the yield and quality of blooms from hybrid Zantedeschia tubers. Scientia Horliculturae 57:133-142.

Funnell, K. A., 1993. Zantedeschia. In: De Hertogh, A. and M. Le Nard (Eds.). The Physiology of Flower of Bulbs. Elsevier. Amsterdam. pp. 683-704.

Funnell, K. A., B. R. MacKay and C. R. O. Lawoco, 1992. Comparative effects of promalin and $\mathrm{GA}_{3}$ on flowering and development of Zantedeschia 'Galaxy'. Acta Horticulturae 292:173-179.

Ngamau, K., 2001. Promoting side shoot development in Zantedeschia aethiopica 'Green Goddess'. Gartenbauwissenschaft 66(2):85-92.

Pérez, C. I. and H. M. J. Juárez, 1998. Incremento en la producción de flores, en alcatraz (calla) Zantedeschia hybrid; mediante la aplicación de $\mathrm{AG}_{3}$ y TDZ. Memoria XVII Congreso de Fitogenética. Acapulco, México. p. 497.

Pizano, M., 1997. Changes in mexican floriculture. Floriculture International. June. pp. $26-28$.

Reiser, A. R, and R. W. Langhans, 1993. Cultivation of Zantedeschia species for potted plant production. Acta Horticulturae 337:87-93.

Reyes, L. A., 1993. Humic acid effect on the stomata conductance and leaf abscission on apple cv. Golden Delicious under tropical conditions. Acta Horticulturae 329:253.

Reynolds, A. G., D. A. Wardle, B. Drough and R. Cantwell, 1995. Gro-Mate soil amendant improves growth of greenhouse-grown 'Chardonay' grapevines. HortScience 30(3):539-542.

Ruiz-Sifre, G., E. Rosa-Márquez and C. E. Flores-Ortega, 1996. Zantedeschia aethiopica propagation by tissue culture. J. Agric. Univ. P.R. 80(3):193-194.

SAS Institute, 1989. SAS User's guide: Statistics. Ver 6, 4th ed. Vols. 1 and 2. SAS Inst., Cary, NC.

Valencia, O. C., 1995. Fundamentos de fitoquímica. Ed. Trillas. México DF. 235 p.

Wright, P. J., 1998. A soft rot of calla (Zantedeschia spp.) caused by Erwinia carotovora subspecies carotovora. New Zealand Journal of Crop and Horticultural Science 26:331-334. 